\title{
Actinomycin V as a Potent Differentiation Inducer of F5-5 Friend Leukemia Cells
}

\author{
Hajimu Morioka, Misako TaKezawa and Hiroshiro Shibai \\ Central Research Laboratories, Ajinomoto Co., Inc., \\ 1-1 Suzuki-cho, Kawasaki-ku, Kawasaki 210, Japan
}

Received April 12, 1984

\begin{abstract}
The cell differentiation system of Friend leukemia cells was applied to screening for new types of antitumor antibiotics. F5-5, Friend leukemia cells, were the most suitable for the assay system due to the stability of their response on repeated culture passages. Antibiotics like mitomycin C, adriamycin and actinomycin $\mathrm{D}$, but not cycloheximide, did not induce detectable benzidine-positive cells among the F5-5 cells in the concentration ranges tested. Among the culture fluids of one thousand and fifty-one streptomycete strains subjected to the assay system, actinomycin V, FL-518 and FL-657 were found to be the most active as inducers. Actinomycin V possessing L-4ketoproline as a substitute for L-proline of actinomycin $\mathrm{D}$ at a concentration of $1.0 \mathrm{ng} / \mathrm{ml}$ caused $39.7 \%$ of the F5-5 cells to become benzidine-positive. Furthermore, actinomycin V inhibited the colony formation of F5-5 cells in the soft agar medium at a concentration of $0.004 \mathrm{ng} / \mathrm{ml}$.
\end{abstract}

Two kinds of assay system have been developed for screening for new antitumor substance; in vivo and in vitro systems. The in vivo systems were effectively adopted to test the antitumor activity of newly found or synthesized compounds using established tumor cells. However, the discovery of an new antitumor compound of microbial origin needs an in vitro antitumor assay system. ${ }^{1 \sim 2)}$ Microorganisms excrete diverse metabolites including antitumor compounds. Due to their extremely low amounts in culture fluids, on in vivo antitumor assay system does not always detect their antitumor activity.

An in vitro detection system for antitumor activity usually depends on the cytotoxic effect on tumor cells, making it difficult to find an effective antitumor compound with selective toxicity. Therefore, we applied the differentiation induction system of Friend leukemia cells to dicover antitumor compounds having selective action on tumor cells. Erythroleukemia cells can differentiate into hemoglobin-positive normal erythroblast-like cells on chemical stimulation. ${ }^{3 \sim 6)}$ These chemicals include bleomycin, adriamycin and actino- mycin D, which are used clinically. ${ }^{7,8)}$

This paper deals with application of the differentiation induction system of Friend leukemia cells, F5-5, to the culture fluids of 1051 strains of streptomycetes. Consequently, we found three potent inducers, one of which was actinomycin V.

\section{MATERIALS AND METHODS}

Cell lines and culture conditions. Friend leukemia cell lines, F5-5 and C9-6, were gifts from Dr. Ikawa, who established them from DDD mice. ${ }^{9}$ F5-5 differentiated to biosynthesize hemoglobin on induction by DMSO, but C9-6 not. Another Friend leukemia cell line, C1745A, originated from DBA/2 mice ${ }^{3)}$ was donated by Dr. Onodera. The culture media were Ham's F-12 supplemented with $10 \%$ fetal calf serum for F5-5 and C9-6, and Dulbecco's MEM supplemented with $10 \%$ fetal calf serum for C1745A. Cells were cultured at $37^{\circ} \mathrm{C}$ in a $5 \%$ $\mathrm{CO}_{2}-95 \%$ air incubator.

96-well plates were used for the assay. The initial cell densities were $2 \times 10^{4}$ cells $/ \mathrm{ml}$ for F5-5 and C9-6, and $1 \times 10^{5}$ cells $/ \mathrm{ml}$ for $\mathrm{C} 1745 \mathrm{~A}$. The Culture volume was $0.2 \mathrm{ml}$ of which $0.02 \mathrm{ml}$ was the microbial culture fluid to be tested or a dilution of it.

Viable cells were determined by the trypan blue dye exclusion method and counted with a Burker-Turk counter. 
To determine the proportion of hemoglobin-containing cells, $0.2 \mathrm{ml}$ of a cell suspension was mixed with $20 \mu 1$ of a freshly prepared benzidine solution ( 10 to 1 mixture of $2 \%$ $3,3^{\prime}$-dimethoxy benzidine in $0.5 \mathrm{M}$ acetic acid and $30 \%$ hydrogen peroxide) ${ }^{10)}$ Cells that were stained blue, indicating the presence of hemoglobin, were counted in a hemacytometer and expressed as the percent of the total cell number.

In order to examine cell tumorigenicity, a colony formation assay was carried out as follows ${ }^{11)}$ : F5-5 cells were suspended in Ham's F-12 medium supplemented with $10 \%$ fetal calf serum to a cell density of $2 \times 10^{3}$ cells/ $\mathrm{ml}$. The cell suspension $(4 \mathrm{ml})$ was mixed with $16 \mathrm{ml}$ of an agar medium consisting of $0.35 \mathrm{ml}$ of $7.5 \% \mathrm{NaHCO}_{3}$, $11.25 \mathrm{ml}$ of Ham's F-12 medium concentrated two times, $2.5 \mathrm{ml}$ of fetal calf serum, $3.75 \mathrm{ml}$ of $3 \%$ agar (Difco) and $7.15 \mathrm{ml}$ of water. The above cell suspension $(0.5 \mathrm{ml})$ was overlaid on $0.5 \mathrm{ml}$ of the agar medium in a 24-well plate. One $\mathrm{ml}$ of the liquid medium containing $20 \%$ a samples was placed on the solidified medium. The agar culture was carried out at $37^{\circ} \mathrm{C}$ for $10 \sim 14$ days in a $5 \% \mathrm{CO}_{2}-95 \%$ air incubator, and the colonies that formed were counted.

Culture conditions for streptomyces and preparation of culture filtrates. The culture medium was composed of $2 \%$ soluble starch, $1 \%$ glucose, $0.2 \%$ yeast extract, $0.1 \%$ $\mathrm{KH}_{2} \mathrm{PO}_{4}, 0.1 \% \mathrm{MgSO}_{4} \cdot 7 \mathrm{H}_{2} \mathrm{O}, 0.7 \%$ bacto-soytone and $0.5 \%$ corn steep liquor. The $\mathrm{pH}$ was adjusted to 7.0 with $\mathrm{NaOH}$. Streptomycetes were cultured at $27^{\circ} \mathrm{C}$ for 7 days in $100 \mathrm{ml}$ of medium in $500 \mathrm{ml}$ Erlenmeyer flasks. The supernatants were sterilized with filter papers (pore size, $0.45 \mu \mathrm{m})$, and subjected to the assay.

Materials. Actinomycin V, actinomycin D, vinblastine, puromycin aminonucleoside, rifamycin SV, valinomycin, cycloheximide, antimycin, erythromycin and azaserine were obtained from Sigma, aureomycin, bacitracin and distamycin A from Serva, mitomycin C from Boehringer Mannheim, daunomycin from Meiji Seika Co., Ltd., and adriamycin from Kyowa Hakko Co., Ltd.

Abbreviation. DMSO, dimethyl sulfoxide.

\section{RESULTS}

\section{Cells employed for the assay system}

Two kinds of Friend leukemia cell lines, F55 and $\mathrm{C} 1745 \mathrm{~A}$, were comparatively studied in relation to their mode of response to induction by DMSO and the stability of their differentiation potency after repeated passages. Table I shows that approximately $1 \%$ of the $\mathrm{C} 1745 \mathrm{~A}$ cells differentiated in the absence of DMSO, however, the F5-5 cells did not at all. This
Table I. Differentiation of Friend Leukemia CElls INDUCED By DMSO

Friend leukemia cells were cultured in the presence of $1.5 \%$ DMSO for 7 days.

\begin{tabular}{lccc}
\hline Cell line & $\begin{array}{c}\text { DMSO } \\
(1.5 \%)\end{array}$ & $\begin{array}{c}\text { Benzidinepositive } \\
\text { cells per } \\
\text { total cells }\end{array}$ & $(\%)$ \\
\hline \multirow{2}{*}{ F5-5 } & - & $0 / 255,0 / 240$ & 0 \\
& + & $98 / 197,83 / 194$ & 46.3 \\
C1745A & - & $1 / 105,1 / 124$ & 0.9 \\
& + & $68 / 108,54 / 98$ & 59.0 \\
\hline
\end{tabular}

Table II. Stability of the Sensitivity of F5-5 AND C1745A CELlS to INDUCTION BY DMSO

The cultures of F5-5 and C1745A were transferred twice a week. After the passage times indicated, the ability of the cells to differentiate was determined. Benzidine-positive cells were scored after the cultivation times indicated in the presence of $1.5 \% \mathrm{DMSO}$.

\begin{tabular}{lccc}
\hline Cell line & Passage & $\begin{array}{c}\text { Cultivation } \\
\text { (days) }\end{array}$ & $\begin{array}{c}\text { Benzidine- } \\
\text { positive cells } \\
(\%)\end{array}$ \\
\hline \multirow{2}{*}{ F5-5 } & 1 & 5 & 34.0 \\
& & 6 & 69.3 \\
& & 7 & 71.2 \\
C1745A & 22 & 6 & 72.0 \\
& 1 & 4 & 64.0 \\
& & 6 & 52.7 \\
& & 7 & 83.2 \\
& 20 & 8 & 63.0 \\
& & 6 & 26.0 \\
\end{tabular}

suggests that a part of the $\mathrm{C} 1745 \mathrm{~A}$ cells spontaneously differentiated into hemoglobinpositive cells. Therefore, it was found to be preferable to use F5-5 in a search for new differentiation inducing agents.

For both F5-5 and C1745A, $50 \sim 70 \%$ of the cells differentiated. This property of F5-5 was continuously kept after repeated passages for 22 times, but not in the case of C1745A, as shown in Table II. The heterogeneity of the $\mathrm{C} 1745 \mathrm{~A}$ cells seemed to cause the unstableness of the response of C1745A to DMSO. In addition, antibiotics such as actinomycin $\mathrm{D}$, mitomycin $\mathrm{C}$ and adriamycin did not cause differenciation of F5-5 (Table IV). ${ }^{7,8)}$ Because of the above mentioned data, F5-5 


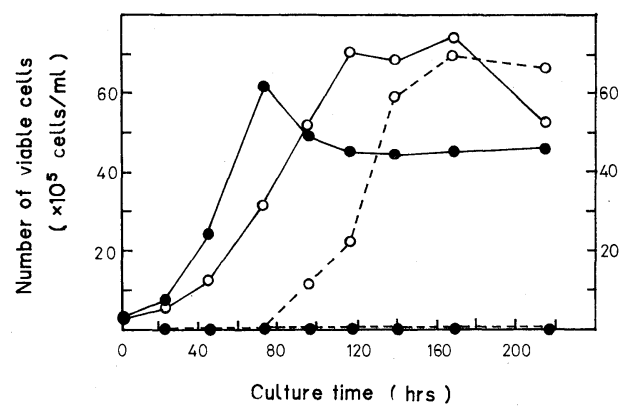

FIG. 1. Rate of Appearance of Benzidine-positive Cells in Culture with DMSO.

$\bigcirc-\bigcirc$, viable cells and $\bigcirc--\bigcirc$, benzidine-positive cells in culture with $1.5 \%$ DMSO;

benzidine-positive cells in a control culture. was employed for the screening assay.

The optimal conditions for differentiation of F5-5 cells were studied in the presence of $1.5 \%$ DMSO (Fig. 1 and Table III). The cells at initial concentrations of 2.5 and $5.0 \times 10^{4}$ cells $/ \mathrm{ml}$ showed their maximal growth $(7 \times$ $10^{5}$ cells $/ \mathrm{ml}$ ) at $115 \mathrm{hr}$. The maximal ratio of benzidine positive cells was observed at $140 \mathrm{hr}$ (Fig. 1).

Initial cell densities of more than $5 \times 10^{4}$ cells $/ \mathrm{ml}$ did not allow sufficient cell differentiation. Therefore, the initial cell density of approximately $2.5 \times 10^{4}$ cells $/ \mathrm{ml}$ and an incubation time of 6 days were taken as the optimum conditions (Table III).

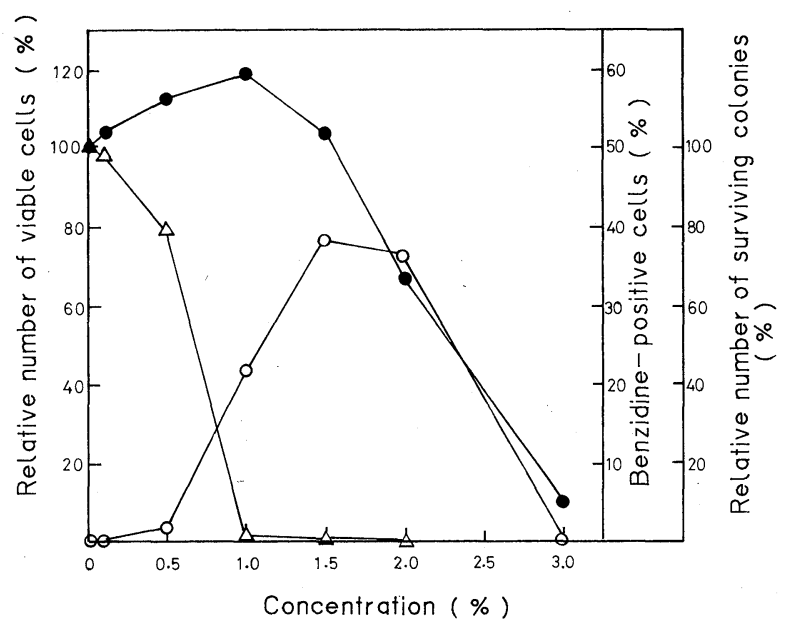

FIG. 2. Effects of DMSO on Hemoglobin Biosynthesis and Colony Formation in the Soft Agar Medium. Relative survival of colonies in the soft agar medium was determined as colonies in the presence of the agent per those in the control culture. - - - viable cells in the liquid medium; - $\mathrm{O}_{-}$, benzidine-positive cells; $-\triangle$ - relative surviving colonies in the soft agar medium.

Table III. Effect of Initial Cell Density on Cell Growth and Differentiation of F5-5

At the times indicated, $0.2 \mathrm{ml}$ of the culture was taken out from $10 \mathrm{ml}$ of the medium containing $1.5 \%$ DMSO in a $25 \mathrm{ml}$ culture flask. Viable and benzidine-positive cells were scored at the times indicated.

\begin{tabular}{|c|c|c|c|c|c|c|c|c|}
\hline \multirow{2}{*}{$\begin{array}{c}\text { Initial cell } \\
\text { density } \\
\left(\times 10^{4} \text { cells } / \mathrm{ml}\right)\end{array}$} & \multicolumn{4}{|c|}{$\begin{array}{c}\text { Viable cells } \\
\left(\times 10^{4} \text { cells } / \mathrm{ml}\right)\end{array}$} & \multicolumn{4}{|c|}{$\begin{array}{c}\text { Benzidine-positive cells } \\
(\%)\end{array}$} \\
\hline & \multicolumn{4}{|c|}{ (days) } & \multicolumn{3}{|c|}{ (days) } & 6 \\
\hline 2.5 & 24 & 48 & 75 & 55 & 0 & 0 & 29.0 & 52.5 \\
\hline 5.0 & 49 & 95 & 75 & 46 & 0 & 0 & 32.5 & 51.0 \\
\hline 10.0 & 73 & 81 & 60 & 41 & 0 & 0 & 12.5 & 14.2 \\
\hline 25.0 & 83 & 65 & 41 & 27 & 0 & 0 & 2.5 & 0 \\
\hline
\end{tabular}


Table IV. Abilities of Various Antibiotics to Induce Benzidine-Positive Cells and INHIBIT CELl Growth of F5-5 IN THE LiQuid Medium

All antibiotics were incubated with the F5-5 cells in the concentration ranges indicated for 6 days. Effective doses of agents $\left(E D_{50}\right)$ giving half maximal growth were calculated from the dose-response curves for the compounds.

\begin{tabular}{|c|c|c|c|}
\hline Antibiotics & $\begin{array}{l}\text { Concentration } \\
\text { ranges } \\
(\mu \mathrm{g} / \mathrm{ml})\end{array}$ & $\begin{array}{c}\mathrm{ED}_{50} \\
(\mu \mathrm{g} / \mathrm{ml})\end{array}$ & $\begin{array}{l}\text { Benzidine- } \\
\text { positive } \\
\text { cells }\end{array}$ \\
\hline \multicolumn{4}{|l|}{ DNA synthesis inhibitor } \\
\hline Mitomycin C & $10^{-6} \sim 10^{0}$ & $5 \times 10^{-1}$ & - \\
\hline \multicolumn{4}{|l|}{ RNA synthesis inhibitors } \\
\hline Actinomycin D & $10^{-6} \sim 10^{0}$ & $5 \times 10^{-2}$ & - \\
\hline Daunomycin & $10^{-5} \sim 2 \times 10^{1}$ & $10^{-3}$ & - \\
\hline Adriamycin & $10^{-6}-10^{0}$ & $5 \times 10^{-3}$ & - \\
\hline Rifamycin SV & $5 \times 10^{-5} \sim 5 \times 10^{-4}$ & $>5 \times 10^{-4}$ & - \\
\hline Distamycin A & $10^{-6} \sim 10^{0}$ & $>10^{\circ}$ & - \\
\hline \multicolumn{4}{|l|}{ Protein synthesis inhibitors } \\
\hline Puromycin aminonucleoside & $5 \times 10^{-5} \sim 5 \times 10^{-4}$ & $>5 \times 10^{-4}$ & - \\
\hline Erythromycin & $10^{-6} \sim 10^{0}$ & $>10^{\circ}$ & - \\
\hline Cycloheximide & $2 \times 10^{-2} \sim 4 \times 10^{-1}$ & $5 \times 10^{-1}$ & + \\
\hline \multicolumn{4}{|l|}{ Energy transfer inhibitors } \\
\hline Antimycin A & $10^{-6} \sim 10^{0}$ & $>10^{\circ}$ & - \\
\hline Valinomycin & $10^{-10} \sim 10^{-3}$ & $5 \times 10^{-5}$ & - \\
\hline \multicolumn{4}{|l|}{ Nucleic acid synthesis inhibitor } \\
\hline Azaserine & $10^{-6} \sim 10^{0}$ & $10^{0}$ & - \\
\hline \multicolumn{4}{|l|}{ Membrane and mitosis inhibitors } \\
\hline Bacitracin & $10^{-6} \sim 10^{0}$ & $>10^{0}$ & - \\
\hline Vinblastine & $10^{-6} \sim 10^{0}$ & $5 \times 10^{-3}$ & - \\
\hline
\end{tabular}

+ , benzidine-positive cells observed; - , no benzidine-positive cells observed.

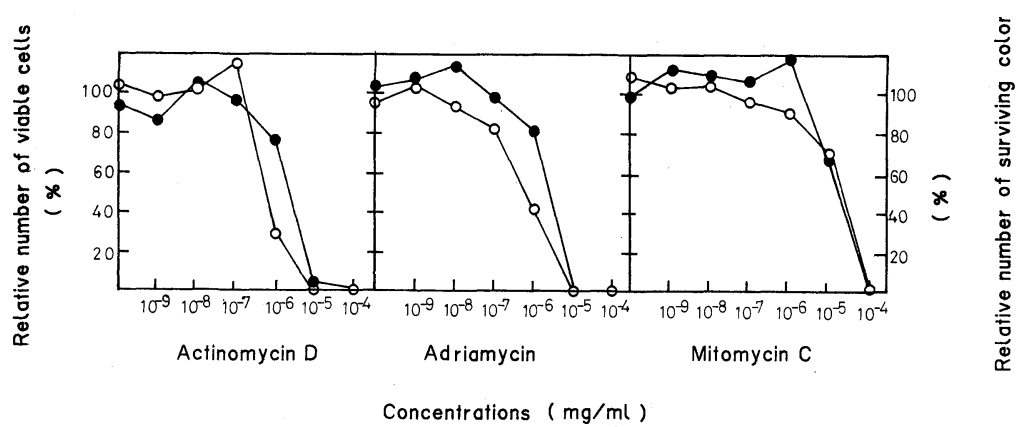

FIG. 3. Effects of Actinomycin D, Adriamycin and Mitomycin C on Viability in the Liquid Medium and Colony Formation in the Soft Agar Medium of F5-5 Cells.

Relative viable cells and colonies in the presence of agents were calculated by comparison with those in the control culture. - - , relative viable cells in the liquid medium; $-\mathrm{O}-$, relative surviving colonies in the soft agar medium.

The loss of the ability to form colonies in the soft agar medium was followed by hemoglobin biosynthesis as shown in Fig. 2. Colony formation in the soft agar medium was markedly inhibited by $1 \%$ DMSO, but cell growth in the liquid medium was not.

\section{Effect of antibiotics on cell differentiation}

Several kinds of antibiotics were examined as to their ability to induce hemoglobin bio- 
synthesis in F5-5 cells. They included mitomycin C, a DNA synthesis inhibitor, actinomycin $\mathrm{D}$, daunomycin, adriamycin, rifamycin SV and distamycin A, RNA synthesis inhibitors, puromycin, erythromycin and cycloheximide, protein synthesis inhibitors, antimycin A and valinomycin, energy transfer inhibitors, and azaserine, bacitracin and vinblastine. ${ }^{12)}$ Antibiotics other than cycloheximide did not induce hemoglobin biosynthesis in F5-5 cells in the concentration ranges tested (Table IV).

Actinomycin D, adriamycin and mitomycin $\mathrm{C}$ inhibited cell growth of F5-5 cells in the soft agar and liquid media (Fig. 3). This suggests that these antibiotics nonspecifically inhibit the growth of F5-5.

\section{Application to culture fluids of streptomycetes}

Samples of culture fluids of one thousand and fifty-one streptomycete strains were subjected to the assay system. Among them, 22 samples showed activity toward F5-5 cells. These samples were examined as to their activity not only toward F5-5 but also toward C9-6 and C1745A (Table V). Two of them, FL-1022 and FL-2371, did not show activity toward C9-6 at a concentration of $10 \%$, but the other twenty samples showed activity toward all three kinds of Friend leukemia cells.
Table V. Minimum Doses of Culture Fluids of Streptomyces Causing F5-5 Cells to Become BENZIDINE-POSITIVE

Culture fluids sterilized with membrane filters (pore size, $0.45 \mathrm{~m} \mu$ ) were added to the cell culture medium at a concentration of $10 \%$. The minimum dose of a sample was expressed as the concentration inducing at least $1 \%$ benzidine positive F5-5 cells.

\begin{tabular}{lccc}
\hline & \multicolumn{3}{c}{ Minimum doses $\left(\times 10^{-20} \%\right.$} \\
\cline { 2 - 4 } Samples & F5-5 & C9-6 & C1745A \\
\hline FL- 53 & 1.95 & 0.98 & 62.5 \\
FL-124 & 7.8 & 1.95 & 250 \\
FL-178 & 62.5 & 0.12 & 62.5 \\
FL-198 & 7.8 & 0.98 & 125 \\
FL-300 & 0.98 & 0.98 & 15.6 \\
FL-514 & 1.95 & 0.12 & 250 \\
FL-518 & 0.49 & 0.24 & 0.98 \\
FL-602 & 0.98 & 0.49 & 31.3 \\
FL-657 & 7.8 & 7.8 & 15.6 \\
FL-928 & 15.6 & 1.95 & 7.8 \\
FL-977 & 62.5 & 62.5 & 62.5 \\
FL-1022 & 62.5 & NI & 62.5 \\
FL-1119 & 500 & 500 & 1000 \\
FL-1189 & 62.5 & 31.3 & 7.8 \\
FL-1208 & 15.6 & 15.6 & 31.3 \\
FL-1448 & 1.98 & 0.98 & 125 \\
FL-1454 & 62.5 & 62.5 & 7.8 \\
FL-1547 & 62.5 & 125 & 62.5 \\
FL-2371 & 7.8 & NI & 62.5 \\
FL-2425 & 7.8 & 3.9 & 500 \\
FL-2454 & 7.8 & 7.8 & 7.8 \\
\hline & & &
\end{tabular}

NI, not induced at $10 \%$.

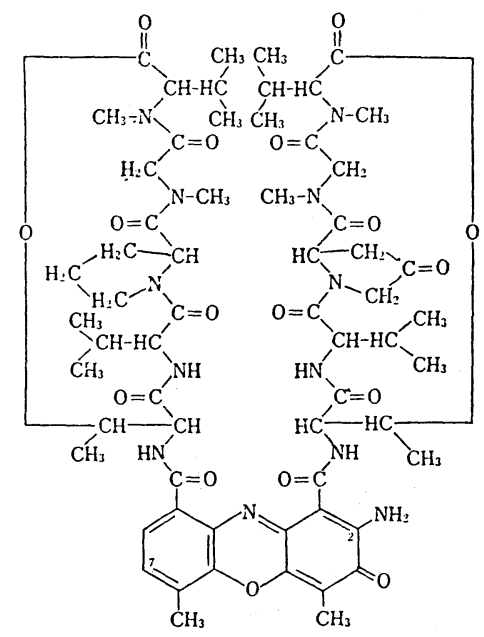

Actinomycin V

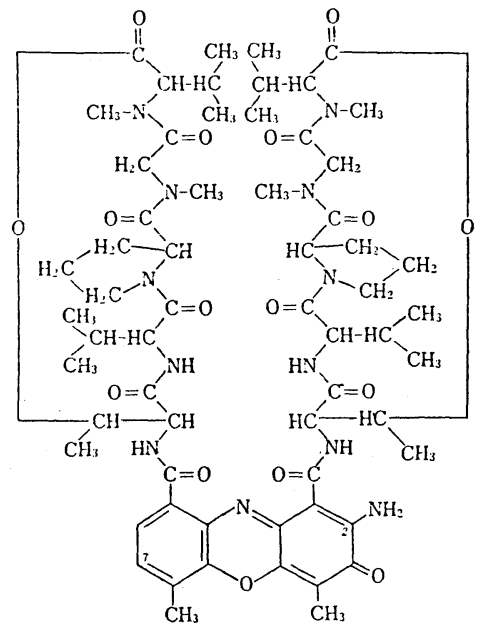

Actinomycin D

FIG. 4. Chemical Structures of Actinomycins V and D. 
Among the twenty samples, FL-518, FL-602 and FL-657 were selected for further studies due to their strong activity and reproducible microbial production. The chemical and biological properties of FL-518 and FL-657 will be described elsewhere.

\section{Actinomycin $V$ as a potent differentiation inducer}

One active inducer (FL-602) that accumulated in the culture fluid of Streptomyces venezuelae was identified as actinomycin $\mathrm{V}$ by analyses of the UV, IR and ${ }^{1} \mathrm{H}$ - and ${ }^{13} \mathrm{C}$ NMR spectra, compared with an authentic sample of actinomycin V. ${ }^{13)}$

Actinomycin $\mathrm{V}$ is structurally different from actinomycin $\mathrm{D}$, possessing L-4-ketoproline as a substitute for L-proline of actinomycin D (Fig. 4).

The deffects of actinomycin $\mathrm{V}$ on cell growth and hemoglobin biosynthesis of F5-5 were compared with those of actinomycin D (Table

Table VI. Effects of Actinomycins V and D on Differentiation and Cell Growth of F5-5

\begin{tabular}{|c|c|c|c|c|c|c|c|}
\hline \multirow{2}{*}{ Compounds } & \multirow{2}{*}{$\begin{array}{l}\text { Conc. } \\
(\mathrm{ng} / \mathrm{ml})\end{array}$} & \multicolumn{3}{|c|}{$\begin{array}{l}\text { Viable cells } \\
\left(\times 10^{4} \text { cells } / \mathrm{ml}\right)\end{array}$} & \multicolumn{3}{|c|}{$\begin{array}{l}\text { Benzidine-positive } \\
\text { cells }(\%)\end{array}$} \\
\hline & & F5-5 & $\mathrm{C} 9-6$ & C1745A & F5-5 & C9-6 & C1745A \\
\hline & 0 & 54.7 & 45.0 & 171 & 0 & 0 & 0.9 \\
\hline \multirow[t]{4}{*}{ Actinomycin V } & 0.01 & 58.6 & 53.8 & 232 & 1.6 & 0 & 0.9 \\
\hline & 0.1 & 39.0 & 60.2 & 226 & 19.8 & 4.8 & 1.0 \\
\hline & 1.0 & 10.8 & 37.1 & 222 & 39.7 & 9.5 & 2.6 \\
\hline & 10.0 & 0 & 0 & 143 & ND & ND & 23.7 \\
\hline \multirow[t]{4}{*}{ Actinomycin D } & 0.1 & 58.8 & 50.9 & 256 & 0 & 0 & 1.1 \\
\hline & 1.0 & 57.8 & 49.3 & 225 & 0 & 0.6 & 0.8 \\
\hline & 5.0 & 15.1 & 33.1 & 147 & 0.9 & 1.7 & 6.8 \\
\hline & 10.0 & 2.0 & 2.7 & 207 & 0 & 2.8 & 22.4 \\
\hline
\end{tabular}

ND, not determined.

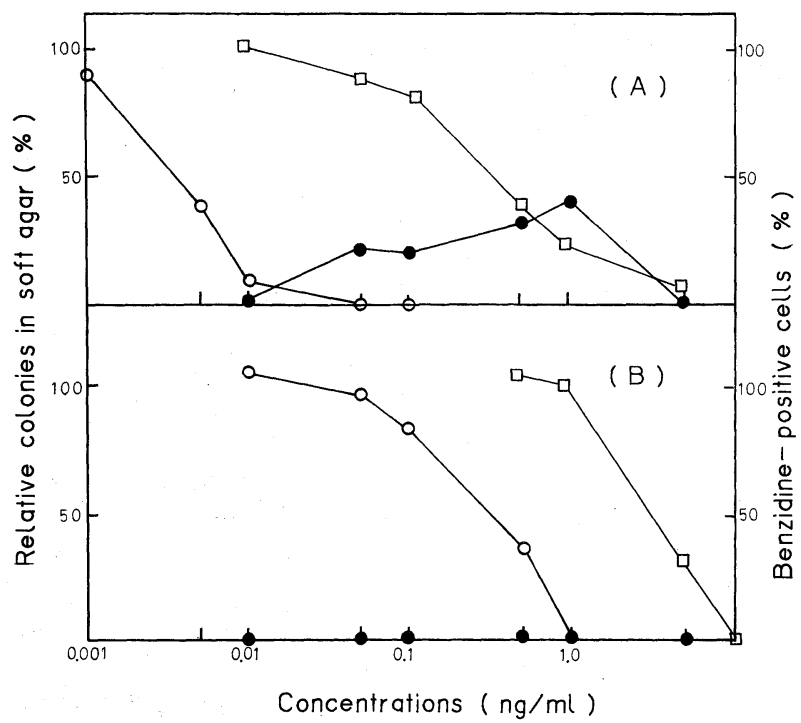

FIG. 5. Effect of Concentrations of Actinomycins V and D on the Cell Growth in the Liquid and Soft Agar Medium and Induction of Benzidine-positive Cells.

Relative viable cells and colonies were calculated by the same method as described in Fig. 3. (A), actinomycin $\mathrm{V}$; (B), actinomycin $\mathrm{D} ;-\square-$, relative viable cells in the liquid medium; - $\mathrm{O}-$, relative surviving colonies in the soft agar medium; - - benzidine-positive cells. 
6). Most noticeable was that actinomycin $\mathrm{V}$ at a concentration of $1.0 \mathrm{ng} / \mathrm{ml}$ caused $39.7 \%$ of the F5-5 cells to become benzidine-positive. The induction by actinomycin $\mathrm{D}$ was very slight, under $1 \%$ benzidine-positive cells being produced at the concentration tested, $5.0 \mathrm{ng} / \mathrm{ml}$. Actinomycin $\mathrm{V}$ at a concentration of $1.0 \mathrm{ng} / \mathrm{ml}$ induced differentiation of $9.5 \%$ of the C9-6 cells, however, actinomycin D only induced $2.8 \%$ at a ten times higher concentration than that of actinomycin $\mathrm{V}$. The C1745A cells showed approximately $23 \%$ differentiation on induction by the two antibiotics at a concentration of $10.0 \mathrm{ng} / \mathrm{ml}$.

As shown in Fig. 5, actinomycin $\mathrm{V}$ also influenced the cell growth of F5-5 cells in the soft agar medium. The half maximal concentrations of actinomycin $\mathrm{V}$ for reduction of the colony formation in the soft agar medium and the cell growth in the liquid medium were approximately $0.004 \mathrm{ng} / \mathrm{ml}$ and $0.3 \mathrm{ng} / \mathrm{ml}$, respectively, and those of actinomycin $\mathrm{D}$ approximately $0.4 \mathrm{ng} / \mathrm{ml}$ and $4.0 \mathrm{ng} / \mathrm{ml}$, respectively.

\section{DISCUSSION}

Differentiation inducing agents for Friend leukemia cells affect more than two different sites on the plasma membrane and DNA, as reported by Nomura and Oishi. ${ }^{14)}$ Actinomycins $\mathrm{V}$ and $\mathrm{D}$ showed cytotoxic effects on F5-5 cells. This suggests that actinomycin $\mathrm{V}$ may have a similar DNA binding property to actinomycin D. ${ }^{15 \sim 18)}$

F5-5 cells could be induced to become benzidine-positive by actinomycin V. C9-6, which is a derivative from the same mouse strain as for F5-5, was weakly sensitive to the induction by both actinomycins $\mathrm{V}$ and $\mathrm{D}$. Sugano et al. reported that T-3-Cl-1, the parent cell line of F5-5 and C9-6, treated with actinomycin $\mathrm{D}$ was completely negative on benzidine staining. ${ }^{19)}$ These results suggest that in F5-5 the specificity of inducer-sensitive sites in DNA be retained to recognize the difference between L-4-ketoproline in actinomycin $\mathrm{V}$ and L-proline in actinomycin $\mathrm{D}$, however, C9-6 may have weakened specificity. The difference between actinomycins $\mathrm{V}$ and $\mathrm{D}$ as to the binding interactions on the DNAbinding sites of F5-5 cells may reflect the specific portions related to cell differentiation.

As for C1745A cells, on the contrary, the affinity of the DNA-binding sites related to the cell differentiation was high enough to permit binding of actinomycins $\mathrm{V}$ and $\mathrm{D}$ and induction of hemoglobin biosynthesis, as reported by Terada et ll. $^{8)}$

The differentiated Friend leukemia cells lost the colony forming ability in the soft agar medium and simultaneously failed to cause leukemia in the syngeneic hosts, as reported by Sugano et al. ${ }^{20)}$ Actinomycin V also inhibited colony formation of F5-5 cells in the soft agar medium at approximately $75 \sim 250$ times lower concentrations than those in the case of the liquid medium, however, actinomycin D showed inhibition at a 10 times lower concentration. These results suggest that actinomycin V may cause the specific inducermediated cessation of neoplastic growth, however, actinomycin D may cause nonspecific growth inhibition. Form the viewpoint of practical use, actinomycin $\mathrm{V}$ is superior to actinomycin D for treating mouse leukemias caused by Friend leukemia cells.

\section{REFERENCES}

1) L. J. Hanka, S. J. Kuentzel, D. G. Martin, P. F. Wiley and G. L. Neil, Recent Results of Cancer Research, 63, 69 (1978).

2) L. W. Weisenthal, J. A. Marsden, P. L. Dill and C. K. Macaluso, Cancer Res., 43, 749 (1983).

3) C. Friend, W. Scher, J. G. Holland and T. Sato, Proc. Natl. Acad. Sci. U.S.A., 68, 378 (1971).

4) C. Friend and W. Scher, Ann. N. Y. Acad. Sci., 243, 155 (1975).

5) P. A. Marks and R. A. Rifkind, Ann. Rev. Biochem., 47, 419 (1978).

6) M. Hozumi, Oncologia, 6, 16 (1983).

7) P. S. Ebert, I. Wars and D. N. Buell, Cancer Res., 36, 1809 (1976).

8) M. Terada, E. Epner, U. Nudel, J. Salmon, E. Fibach, R. A. Rifkind and P. A. Marks, Proc. Natl. Acad. Sci. U.S.A., 75, 2795 (1978).

9) Y. Ikawa, Y. Inoue, M. Aida, R. Kameji, C. Shibata and H. Sugano, Bibl. Haemat., 43, 37 (1976). 
10) S. Orkin, F. I. Harosi and P. Leder, Proc. Natl. Acad. Sci. U.S.A., 71, 98 (1975).

11) Y. Ikawa, M. Obinata and H. Sugano, Gann Monogr. on Cancer Res., 24, 263 (1979).

12) N. Tanaka, "Mechanism of Action of Antibiotics," Univ. of Tokyo Press, Tokyo, 1972.

13) H. Umezawa, "Index of Antibiotics from Actinomycetes," Univ. of Tokyo Press, Tokyo, 1967, p. 91 .

14) S. Nomura and M. Oishi, Proc. Natl. Acad. Sci. U.S.A., 80, 210 (1983).

15) W. Muller and D. M. Crothers, J. Mol. Biol., 35, 251 (1968).
16) H. M. Sobell and S. C. Jain, J. Mol. Biol., 68, 21 (1972)

17) S. K. Sengupta, J. E. Anderson, Y. Kogan, D. H. Trites, W. R. Beltz and M. S. Madhavarao, J. Med. Chem., 24, 1052 (1981).

18) S. K. Sengupta, J. E. Anderson and C. Kelley, J. Med. Chem., 25, 1214 (1982).

19) H. Sugano, M. Furusawa, T. Kawaguchi and Y. Ikawa, Bibl. Haemat., 39, 943 (1973).

20) H. Sugano, T. Kawaguchi, M. Furusawa and Y. Ikawa, "Comparative Leukemia Research 1973," Univ. of Tokyo Press, Tokyo, 1975, p. 221. 